\title{
Monitoring of Physical Parameters in Organic Waste Composting
}

\author{
Ana Kaline da Costa Ferreira ${ }^{1}$, Nildo da Silva Dias ${ }^{1}$, Daianni Ariane da Costa Ferreira ${ }^{1}$, \\ Francisco Souto de Sousa Júnior ${ }^{2}$, Moadir de Sousa Leite ${ }^{1}$, Vania Christina Nascimento Porto ${ }^{1}$, \\ Cleyton dos Santos Fernandes ${ }^{1}$, Bruno Goulart de Azevedo Souza ${ }^{1}$, Jucirema Ferreira da Silva ${ }^{1}$ \\ \& Luciara Maria de Andrade ${ }^{3}$ \\ ${ }^{1}$ Center of Agrarian Sciences, Federal Rural University of the Semi-arid, Mossoró, RN, Brazil \\ ${ }^{2}$ Department of Exact, Technological and Human Sciences, Federal Rural University of the Semi-arid, Angicos, \\ RN, Brazil \\ ${ }^{3}$ City Hall of Mossoró, RN, Brazil \\ Correspondence: Moadir de Sousa Leite, Center of Agrarian Sciences, Federal Rural University of the Semi-arid, \\ Mossoró, RN, Brazil. Tel: 55-088-99984-2356. E-mail: moadir@outlook.com
}

$\begin{array}{lc}\text { Received: April 17, } 2018 & \text { Accepted: May 19, } 2018 \quad \text { Online Published: June 15, } 2018 \\ \text { doi:10.5539/jas.v10n7p464 } & \text { URL: https://doi.org/10.5539/jas.v10n7p464 }\end{array}$

\begin{abstract}
The volume of biodegradable solid waste and its inadequate disposal have led to serious environmental problems, requiring efficient measures that prioritize the recycling of these wastes, promoting sustainability. The objective of this research was to monitor the behavior of physical parameters during the organic waste composting process. For this, 5 piles of organic waste were built through the composting technique developed according to the windrow method. The piles were composed of $70 \%$ of plant material, and $30 \%$ varied between manure and food remains. The piles were composed of $70 \%$ of plant material, and $30 \%$ varied between manure and food remains. The proportions were: I pile, 1:1 (15\% manure and 15\% rest of food); Pile II, 2:1 (20\% manure and 10\% rest of food); Cell III, 1:2 (10\% manure and 20\% rest of food); (30\% manure and $0 \%$ rest of food) and the V pile in the ratio of $0: 3(0 \%$ manure and $30 \%$ rest of food). The evaluated parameters were temperature, moisture, $\mathrm{pH}, \mathrm{TOC}$, $\mathrm{TN}$ and $\mathrm{C} / \mathrm{N}$ ratio. During the process of compost maturation, the parameters evaluated were kept within the established standards for the composting process.
\end{abstract}

Keywords: composting, environment, environmental sustainability, organic matter, solid waste

\section{Introduction}

One of the great challenges of modern society is the establishment of a wide system and efficient management of solid waste, principally due to the process of urban expansion and cities urbanization, which triggers population growth, leading to high production, exaggerated consumption and environmental problems.

In Brazil, the rate of Urban Solid Waste generation (USW) in 2014 was approximately 78.6 million tons, attributing an increase of $2.9 \%$ compared to the previous year. In this period, the population growth rate, which was $0.9 \%$, was lower than the rate of waste production. Comparing the years of 2013 and 2014, it was observed that the generation of USW per capita in 2014 had an increase of $2.02 \%$, however, this increase was also verified in the collection of USW, presenting a total of $3.20 \%$ a more than the year 2013 . Checked that, comparing the generated in 2013 and 2014, Brazil stopped collecting approximately 7 million tons of USW per year, thereby deduced it that these solid wastes were improperly destined (IBGE, 2014).

With the expansion and urban areas densification, problems have increased, since most Brazilian cities do not follow the accelerated pace of this growth with adequate sanitary infrastructure (Rezende et al., 2013).

The inadequate disposal of the USW promotes serious consequences, such as the silting of rivers and canals due to the release of debris in these places, the contamination of the water table affecting their home use. Still promotes soil contamination through the infiltration of percolated liquids generated from of the process of decomposition and degradation of the organic fraction, the proliferation of insects, rodents, disease transmitters, and the problem of the presence of the collectors in the places where the solid waste are deposited in the open sky (Leal, 2017).

Therefore, environmental and social pressures have encouraged the immediate search for solutions for organic solid waste, seeing that its generation rate is well above its rate of degradation in the environment (Fiori et al., 
2008). In Brazil, household solid waste presents a high percentage of organic residues formed by leftover foods and peels of fruits and vegetables (Santos et al., 2014).

Composting emerges as an efficient way to obtain biodegradation of organic waste, defended as a controlled process, reducing the pollutant potential and contaminant of these residues, besides converting them into an organic compound capable of replenishing the nutrients in the soil (Domínguez \& Gómez, 2010). Thus, the compounds can be used in agriculture as a fertilizer, as an alternative to chemical fertilizers that are detrimental to the environment, besides constituting gains for public administration, as it reduces transport costs for landfills (Costa et al., 2015).

According to Magalhães et al. (2006), the organic compound is an excellent conditioner for the soil, being able to provide improvements in its physical properties, increasing water retention capacity and macroporosity. As well can improve the chemical and physico-chemical properties, increasing the availability of macro and micronutrients and the capacity of cation exchange and also improve the biological properties, since it stimulates microorganisms beneficial proliferation to the agricultural crops.

However, there are factors that interfere in the maturation and quality of the final composting product and should be constantly monitored and evaluated. Of these factors, Pedrosa et al. (2013) points out mainly those related to the inhibition and/or development of microbiological activity, such as temperature, $\mathrm{pH}$, aeration, $\mathrm{C} / \mathrm{N}$ ratio and moisture content.

In this context, the objective was to monitor the behavior of physical parameters during the organic waste composting process.

\section{Material and Methods}

The Research was developed in the Associação Comunitária Reciclando para a Vida (ACREVI), located in the Mossoró Municipality, RN ( $5^{\circ} 14^{\prime} 9^{\prime \prime} \mathrm{S}$ and $37^{\circ} 18^{\prime} 59^{\prime \prime} \mathrm{W}, 18 \mathrm{~m}$ asl.). The characterization of the region is very dry and very hot $\mathrm{BSwh}^{1}$ climate, presenting irregular rainfall, with an annual average of $673.9 \mathrm{~mm}$, with a dry season, generally comprising the period from June to January and a rainy season, between the months of February and May. On average, the temperature is $27.4{ }^{\circ} \mathrm{C}$, reaching $36.0{ }^{\circ} \mathrm{C}$ and $21.0{ }^{\circ} \mathrm{C}$, maximum and minimum, respectively, with relative humidity of $60.7 \%$ (Carmo-Filho et al., 1991).

Five piles of conical shaped cones with dimensions of approximately $1.60 \mathrm{~m}$ in height and $2.00 \mathrm{~m}$ in diameter were constructed and spaced apart and parallel according to the "windrow" method (Pereira Neto, 2007), constructed with $70 \%$ of vegetal material and $30 \%$ of manure and food remains, occurring variation in the proportion of dung and food remains. The proportions were: I pile, $1: 1$ (15\% manure and $15 \%$ rest of food); pile II, 2:1 (20\% manure and 10\% rest of food); cell III, $1: 2$ (10\% manure and $20 \%$ rest food); ( $30 \%$ manure and $0 \%$ rest of food) and the $\mathrm{V}$ pile in the ratio of 0:3 ( $0 \%$ manure and $30 \%$ rest of food).

The plant material used in the production of the piles came from the pruning of trees in the urban area of the city of Mossoró, collected by the city's urban cleaning service. Bovine manure came from the UFERSA cattle breeding sector, and household organic waste came from a popular restaurant in the commercial center of the municipality of Mossoró. Approximately 7 tons of vegetable pruning and $1500 \mathrm{~kg}$ of cattle manure and organic household waste collected by that. The composting process occurred in the period from June to December 2016.

The piles were mobilized manually and that occurred in the first week, every three days, and then every ten days, and these were irrigated daily by hand.

The compost piles were installed in an open location, and it is necessary to monitor climatic factors such as temperature, humidity and rainfall. These factors were recorded monthly and obtained from the meteorological station of UFERSA.

The samples were collected weekly (during the whole experiment) and carried out using the quartering method, procedure-NBR 10.007 of 1987.

From the collection were realized the analyses:

a) Temperature: performed every three days in the first week, and every ten days thereafter, always at different heights (top, center and base), using a digital spike type thermometer with alarm and scale $\left(-50+300{ }^{\circ} \mathrm{C}\right)$, resolution of $1{ }^{\circ} \mathrm{C}$ and accuracy of $-10{ }^{\circ} \mathrm{C}$ to $100{ }^{\circ} \mathrm{C}= \pm 1{ }^{\circ} \mathrm{C}$, brand INCOTERM. Considering for discussion the later results, the higher observed temperature.

b) Moisture: performed weekly and in triplicate, where a sample from each pile was removed and transferred to a greenhouse $\left(65^{\circ} \mathrm{C}\right)$ until mass stabilization occurred (Pedrosa et al., 2013). Thus, the degree of moisture was calculated according to the equation: $\mathrm{U}\left(65^{\circ} \mathrm{C}\right)=100$ (Initial weight - Constant mass)/Initial weight. 
c) pH: performed every three days in the first week and thereafter every ten days. For this analysis, a random sample of each cell was collected, weighed $10 \mathrm{~g}$ and $50 \mathrm{~mL}$ of deionized water added to the sample. The mixture was stirred manually for $1 \mathrm{~min}$. Then it was allowed to stand for $30 \mathrm{~min}$ and was taken to the pHmetro for reading.

d) Total Organic Carbon (TOC) and Total Nitrogen (TN): to quantify these parameters, four collections were performed; three during the degradation phase of the compounds and one with 90 days after the beginning of the composting process. The determination of TOC was performed by the wet oxidation method with external heating (Yeomans \& Bremner, 1988) and the TN comprised the digestion of the sample to convert organic nitrogen to ammonium ion $\left(\mathrm{N}-\mathrm{NH}_{4}{ }^{+}\right)$and determination of $\mathrm{N}^{-\mathrm{NH}_{4}}{ }^{+}$which was analyzed after steam distillation followed by titration with dilute sulfuric acid (Tedesco et al., 1995). From the results of the TOC and TN analyzes, the $\mathrm{CN}$ ratio was calculated according to the equation: $\mathrm{CN}=\% \mathrm{TOC} / \% \mathrm{TN}$.

The results interpretation was based on observations and collected during the composting process. Analyzes in triplicate were then evaluated and the means were calculated to generate the graphs in the Microsoft Excel 2010 program.

\section{Results and Discussion}

There was no situation in which rainfall would interfere with the composting process, once low rainfall was recorded during the maturation process of the compost, in which rainfall was recorded only in June and July (18.5 and $17.5 \mathrm{~mm}$ respectively). The other months, related to the period of the experiment, were not registered precipitation occurrence, and it can be confirmed with the values observed for the relative humidity of the air, which presented around 54 to $67 \%$.

The mean daily temperature recorded during the experiment period was $30^{\circ} \mathrm{C}$, considered as hot days. These days may have directly influenced the temperatures of the compost piles, since they were exposed in an open place and, therefore, the thermal changes became intense.

Regarding the temperature parameter, it was observed that all the piles presented many oscillations during the composting process (Figure 1A).

In general, piles I, II and IV showed a progressive increase in temperature, reaching temperatures above $50{ }^{\circ} \mathrm{C}$ in the interval between 30 and 50 days after piling. Rodrigues et al. (2016) ratifies the result as adequate, because according to him, the system in the process of composting should reach temperatures of 45 to $65^{\circ} \mathrm{C}$ in the first days of activity, these values being indicative of satisfactory conditions of nutrient balance.

When the waste are piled, the phase of the mesophilic flora begins the degradative process of the residues. The energy released in the form of heat is retained in the compost mass causing the temperature to rise. With favorable conditions of moisture, aeration and nutrients, the mesophilic microorganisms multiply by increasing the degradation activity, and consequently, the temperature reaches the thermophilic range rapidly (Pereira et al., 2013). According to Heck et al. (2013), the thermophilic phase provides the reduction of bacterial populations from both domestic organic waste and food residues, contributing to the stabilization of the compound.

The temperature of the pile is one of the major indications of the efficiency of the composting process. Pereira Neto (2007) points out that the decomposition rate is maximum at temperatures between 45 and $55^{\circ} \mathrm{C}$. However, it is necessary during the process temperatures to reach values higher than $55^{\circ} \mathrm{C}$, in order to ensure the sanitizing of the compound, destroying pathogenic microorganisms and weed seeds.

In spite of the temperature oscillations observed in the different piles during the composting process, resulting from the degradation of the organic matter, all at the end of the process presented mesophilic temperatures, that is, close to the environment temperature. 

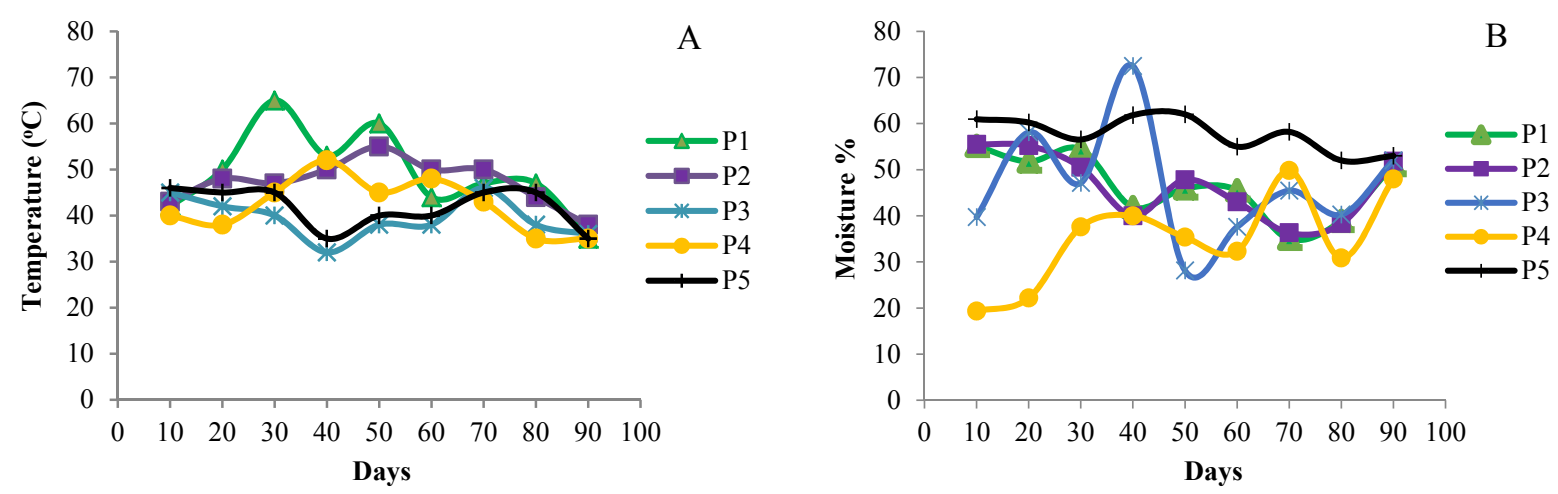

Figure 1. Variation of temperature (A) and moisture (B) in the five piles during the composting process

Note. P1: 15\% M and 15\% RF; P2: 20\% M and 10\% RF; P3: 10\% M and 20\% RF; P4: 30\% M; P5: 30\% RF.

About the moisture content (Figure 1B), it is possible to observe that variations occurred in all five piles during the whole process. The highest moisture amplitude was observed between IV (30\% manure) and V ( $30 \%$ food waste) piles, since they had only one type of material mixed with the plant material, which was common between all the piles. The moisture content of a compound can vary due to the different types of component material. However, Pereira Neto (2007) points out that the maintenance of the pile moisture between 40 and $60 \%$ is of great importance for the maintenance of the microbiological degradation activity. Despite the great variation throughout the process, the final moisture of all the piles studied turned around $50 \%$.

High moisture in pile $\mathrm{V}$ triggered a decrease in temperature and odor dropping due to lack of oxygenation. Pedrosa et al. (2013) reported that cases where moisture is very high might reduce the availability of oxygen, leading to the development of an anaerobic decomposition process of organic materials, causing the emanation of unpleasant odors and nutrient losses.

The $\mathrm{pH}$ of all the piles was similar (Figure 2A), slightly acidic (5.5 to 6.7) at the beginning of the composting process, becoming alkaline gradually until the end of the process. According to Jahnel et al. (1999), it is generally observed a reduction of $\mathrm{pH}$ at the beginning of composting, becoming the compound slightly acidic, resulting from the decomposition of organic matter by fungi and bacteria, which causes release of acids in this stage. Afterwards, these acids are decomposed until they are completely oxidized, reaching in the final stage of the process a slightly alkaline $\mathrm{pH}$ (Pedrosa et al., 2013).

Pereira Neto (2007) also affirms that high values of $\mathrm{pH}$ in the compounds can be seen as a great benefit, since it is possible to be applied in the correction of acid soils.
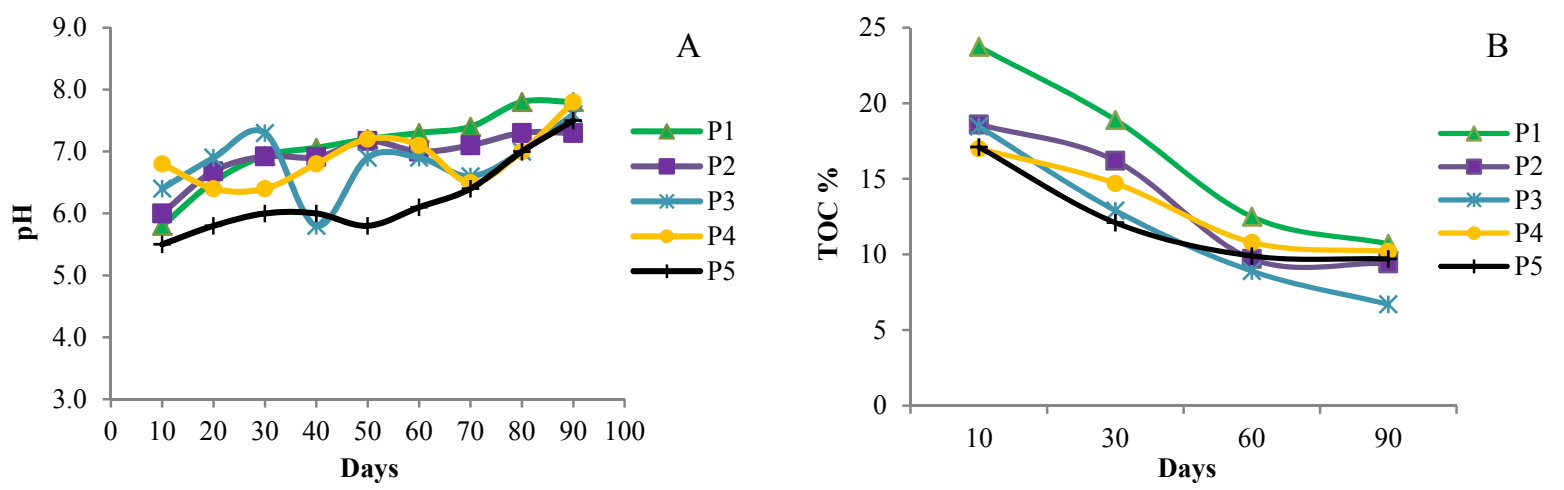

Figure 2. Variation of $\mathrm{pH}(\mathrm{A})$ and TOC (B) in the five piles during the composting process

Note. P1: $15 \% \mathrm{M}$ and 15\% RF; P2: 20\% M and 10\% RF; P3: 10\% M and 20\% RF; P4: 30\% M; P5: 30\% RF.

In the TOC analysis (Figure $2 \mathrm{~B}$ ), there was a gradual reduction of the values of this parameter throughout the composting process for all the piles studied. The higher initial amount of TOC is associated with the composition 
of the piles, composed of materials extremely rich in organic matter that contribute significantly to the increase of the carbon stock. Thus, the amount of TOC at the beginning of composting is high and decreases over time due to its use as a source of energy by microorganisms (Pedrosa et al., 2013), occurring the transformation of residues used in organic materials, which will be available to the plants through the organic compounds formed.

In the five piles studied, there was a difference in TOC values among, and this variation is a consequence of the diversity of materials used in each pile. From the beginning of the composting process, the pile I presented a differential in the contribution of COT, extending to the final phase. Possibly, the rapid performance of the microbial activity provided an increase in the rate of degradation of the organic matter triggering this increase of total organic carbon.

Regarding the evolution of organic nitrogen and composting days, the five piles presented similar results, evidencing a decrease generally in all piles in the first 30 days of composting (Figure $3 \mathrm{~A}$ ). This fall may be a consequence of the growth of nitrifying microorganisms that transform the ammoniacal nitrogen into nitrite and nitrate, not measured in the present study due to the limitation of the method used in the determination of nitrogen. Pedrosa et al. (2013), monitoring physical parameters in the composting of agroindustrial residues observed that there was a reduction of $21.3 \%$ in TN content during composting.

Piles I and II showed few TN losses in the first 30 days, with the largest reductions observed in piles III, IV and $\mathrm{V}$, possibly as a consequence of the temperature and moisture content variations of the piles during the composting process. Raviv et al. (2004) reported that TN losses during the composting process may increase or decrease as the temperature oscillates and the intensity with which the gas exchanges with the outside.
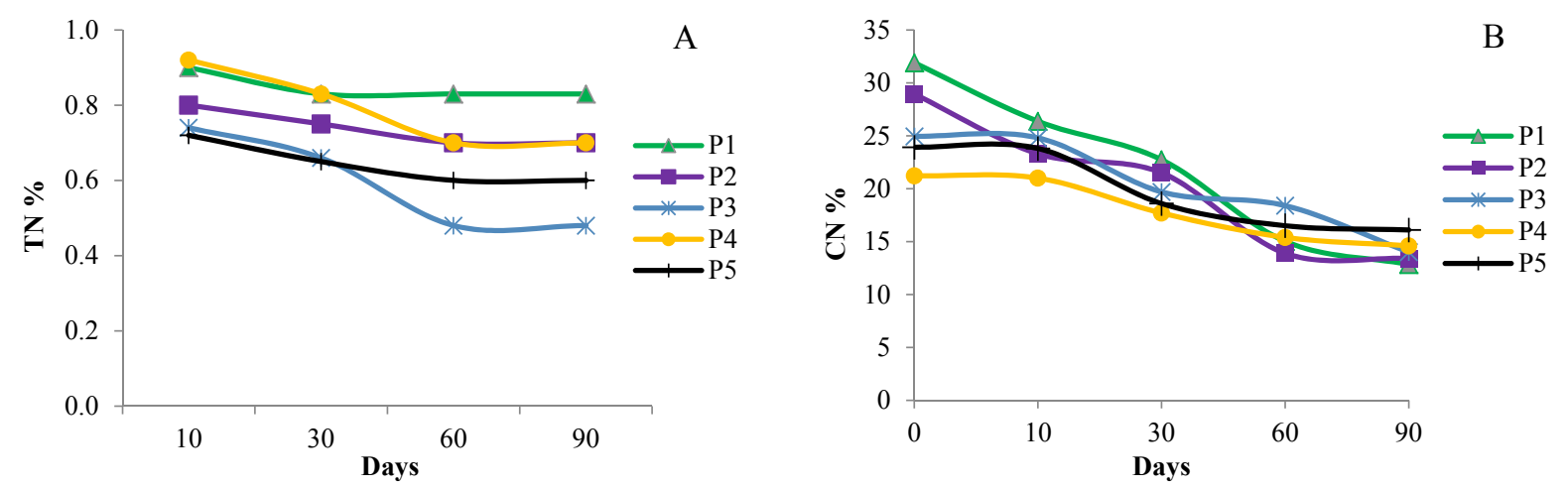

Figure 3. Variation of TN (A) and $\mathrm{C} / \mathrm{N}(\mathrm{B})$ ratio in the five piles during the composting process

Note. P1: 15\% M and 15\% RF; P2: 20\% M and 10\% RF; P3: 10\% M and 20\% RF; P4: 30\% M; P5: 30\% RF.

About the $\mathrm{C} / \mathrm{N}$ ratio (Figure $3 \mathrm{~B}$ ), it was found that in all piles the ratio decreased during the composting process. However, the result at the beginning of the process is not the same for all piles due to the variety of organic waste used. According to Corrêa et al. (2007) and Caricasole et al. (2011), the initial C/N ratio is very important for the composting process and must be calculated, since this factor can directly influence the composting time.

In all the studied piles significant reductions of the $\mathrm{C} / \mathrm{N}$ ratio occurred already in the first 40 days of composting, being this reduction a consequence of the oscillation of moisture and temperature recorded during the process. Pedrosa et al. (2013) points out that, for a complete composting process, several physical parameters must be controlled, among them, are temperature, moisture and consequently aeration.

Regarding to the final phase of the composting process, there are many divergences in reference to the ideal $\mathrm{C} / \mathrm{N}$ ratio. Pereira Neto (2007) ensures an ideal range for the $\mathrm{C} / \mathrm{N}$ ratio between 8 and 12/1. Meanwhile, Jiménez and Garcia (1989) reported that the ideal is to make a relation between the final $\mathrm{C} / \mathrm{N}$ and the initial $\mathrm{C} / \mathrm{N}$, which should be less than 0.7 to indicate a measure of satisfactory degradation.

In this context, at the end of the composting process, all the piles presented satisfactory results regarding the maturation of the compounds, with final $\mathrm{C} / \mathrm{N}$ ratio and initial $\mathrm{C} / \mathrm{N}$ ratio of $0.40 ; 0.46 ; 0.56 ; 0.68$ and 0.67 in stacks I, II, III, IV and V, respectively. 


\section{Conclusions}

During the maturation process of the compost, the parameters temperature, moisture, $\mathrm{pH}, \mathrm{TOC}, \mathrm{TN}$ and $\mathrm{C} / \mathrm{N}$ ratio were kept within the established standards for the composting process.

\section{References}

Caricasole, P., Provenzano, M. R., Hatcher, P. G., \& Senesi, N. (2011). Evolution of organic matter during composting of different organic wastes assessed by CPMAS 13C NMR spectroscopy. Waste Management, 31, 411-415. https://doi.org/10.1016/j.wasman.2010.09.020

Carmo-Filho, F., Sobrinho, J. E., \& Maia Neto J. M. (1991). Dados climatológicos de Mossoró: Um município semi-árido nordestino (p. 121). Mossoró, RN: UFERSA.

Corrêa, R. S., Fonseca, Y. M., \& Corrêa, A. S. (2007). Produção de biossólido agrícola por meio da compostagem e vermicompostagem de lodo de esgoto. Revista Brasileira de Engenharia Agrícola e Ambiental, 11(4), 420-426. https://doi.org/10.1590/S1415-43662007000400012

Costa, A. R. S., Ximenes, T. C. F., Ximenes, A. F., \& Beltrame, L. T. C. (2015). O processo da compostagem e seu potencial na reciclagem de resíduos orgânicos. Revista Geama, 3(1), 116-130. Retrieved from http://www.journals.ufrpe.br/index.php/geama/article/view/1073/1442

Domínguez, J., \& Gómez-Brandón, M. (2010). Ciclos de vida de las lombrices de tierra aptas para el vermicompostaje. Acta Zoológica Mexicana, 26(2), 309-320. https://doi.org/10.21829/azm.2010.262896

Fiori, M. G. S., Schoenhals, M., \& Follador, F. A. C. (2008). Análise da evolução tempo-eficiência de duas composições de resíduos agroindustriais no processo de compostagem aeróbia. Engenharia Ambiental, 5(3), 178 -191. Retrieved from http://ferramentas.unipinhal.edu.br/engenhariaambiental/viewarticle.php?id=164

Heck, K., Marco, E. G., Hahn, A. B. B., Kluge, M., Spilki, F. R., \& Sandra, S. T. Van Der. (2013). Temperatura de degradação de resíduos em processo de compostagem e qualidade microbiológica do composto final. Revista Brasileira de Engenharia Agrícola e Ambiental, 17(1), 54-59. https://doi.org/10.1590/S1415-436 62013000100008

IBGE (Instituto Brasileiro de Geografia e Estatística). (2014). Manejo de resíduos sólidos. Retrieved from https: //www.ibge.gov.br/home/estatistica/populacao/condicaodevida/pnsb2008/defaulttabpdf_man_res_sol.shtm

Jahnel, M. C., Melloni, R., \& Cardoso, E. J. B. N. (1999). Maturidade de composto de lixo urbano. Scientia Agricola, 56(2), 301-304. https://doi.org/10.1590/S0103-90161999000200007

Jiménez, E. I., \& García, V. P. (1989). Evaluation of city refuse compost maturity: A review. Biological Wastes, 27, 115-142. https://doi.org/10.1016/0269-7483(89)90039-6

Leal, A. (2017). Análise da disposição final dos resíduos sólidos urbanos no Distrito de Pilar-Ba. Revista de Comunicação e Cultura no Semiárido, 1(4), 1-12. Retrieved from https://www.revistas.uneb.br/index.php/ comsertoes/article/download/3106/2020

Magalhães, M. A., Matos, A. T., Denículi, W., \& Tinoco, I. F. F. (2006). Compostagem de bagaço de cana-de-açúcar triturado utilizado como material filtrante de águas residuárias da suinocultura. Revista Brasileira de Engenharia Agrícola e Ambiental, 10(2), 466-471. https://doi.org/10.1590/S1415-436620 06000200030

Pedrosa, T. D., Farias, C. A. S., Pereira, R. A., \& Farias, E. T. R. (2013). Monitoramento dos parâmetros físico-químicos na compostagem de resíduos agroindustriais. Revista Nativa, 1(1), 44-48. https://doi.org/ 10.14583/2318-7670.v01n01a08

Pereira Neto, J. T. (2007). Manual de compostagem: processo de baixo custo (p. 81). Viçosa: UFV.

Raviv, M., Medina, S., Krasnovsky, A., \& Ziadna, H. (2004). Organic matter and nitrogen conservation in manure compost for organic agriculture. Compost Science \& Utilization, 12(1), 6-10. https://oi.org/ 10.1080/1065657X.2004.10702151

Rezende, J. H., Carboni, M., Murgel, M. A. T., Capps, A. L. A. P., Teixeira, H. L., Simões, G. T. C., ... Oliveira, C. A. (2013). Composição gravimétrica e peso específico dos resíduos sólidos urbanos em Jaú (SP). Engenharia Sanitária e Ambiental, 18(1), 1-8. https://doi.org/10.1590/S1413-41522013000100001

Rodrigues, A. C., Baum, C. A., Formentini, J., Schmachtenberg, N., Trevisan, G. M., \& Silva, A. C. G. (2016). Avaliação do processo de compostagem utilizando lodo de Estação de Tratamento de Efluentes de laticínio. Ciência e Natura, 38(2), 610-619. https://doi.org/10.5902/2179460X18875 
Santos, A. T. L., Henrique, N. S., Shhlindwein, J. A., Ferreira, E., \& Stachiw, R. (2014). Aproveitamento da fração orgânica dos resíduos sólidos urbanos para produção de composto orgânico. Revista Brasileira de Ciências da Amazônia, 3(1), 15-28. Retrieved from http://www.periodicos.unir.br/index.php/rolimdemoura/ article/view/1177/1261

Tedesco, M. J., Gianello, C., Bissani, C. A., Bohnen, H., \& Volkweiss, S. J. (1995). Análise de solo, plantas e outros materiais (p. 173). Porto Alegre: UFRGS.

Yeomans, J. C., \& Bremner, J. M. (1988). A rapid and precise method for routine determination of organic carbon in soil. Communications in Soil Science and Plant Analysis, 19, 1467-1476. https://doi.org/10.1080/ 00103628809368027

\section{Copyrights}

Copyright for this article is retained by the author(s), with first publication rights granted to the journal.

This is an open-access article distributed under the terms and conditions of the Creative Commons Attribution license (http://creativecommons.org/licenses/by/4.0/). 